\title{
Light Olefins Production in a Fixed Bed Reactor Using Alumina Supported Iron-Cobalt-Cerium Oxide Nanocatalysts Prepared by Impregnation Procedure: Effect of Preparation Conditions on Nanocatalyst Performance
}

\author{
Ali Akbar Mirzaei ${ }^{1 \mathbb{D}}$, Behdokht Hashemi Hosseini ${ }^{1 \mathbb{D}}$, Sajjad Porgar ${ }^{2, * \mathbb{D}}$ \\ 1 Department of Chemistry, Faculty of Sciences, University of Sistan and Baluchestan, Zahedan, Iran; \\ Behdokht.hashemi.hossein@gmail.com (B.H.H.); \\ 2 Department of Chemical Engineering, South Tehran Branch, Islamic Azad University, Tehran, Iran; \\ sajjad.porgar@gmail.com (S.P.); \\ * Correspondence: sajjad.porgar@gmail.com;
}

Scopus Author ID 57202874495

Received: 15.11.2020; Revised: 9.12.2020; Accepted: 10.12.2020; Published: 13.12.2020

\begin{abstract}
In this study, pretreatment conditions such as impregnation time and temperature and drying time and temperature for the production of the iron-cobalt-cerium catalyst with impregnation method as a first step for controlling the synthesis of a new type of three similar metal phase ratio were determined by the Taguchi method. A microtubular fixed bed reactor tested the catalysts' performance under constant conditions according to conversion. The activity and selectivity toward propylene and ethylene have been calculated. The catalyst, which impregnated at $90{ }^{\circ} \mathrm{C}$ for $4 \mathrm{hr}$ and dried at $120{ }^{\circ} \mathrm{C}$ for $24 \mathrm{hr}$, had the best catalytic performance. According to previous studies, the catalyst calcined and the reactor test was performed in the constant and optimum condition such as calcinations in $600{ }^{\circ} \mathrm{C}$ for $6 \mathrm{hr}$, reduction with $\mathrm{H} 2$ (flow $=30 \mathrm{~mL} \cdot \mathrm{min}^{-1}$ ) for $90 \mathrm{~min}$ and $\mathrm{P} \sim 1$ atm and also the reaction terms was $\mathrm{H} 2: \mathrm{CO}=1$ (flow $\mathrm{H} 2=37.5 \mathrm{~mL} \cdot \mathrm{min}^{-1}$ and $\mathrm{CO}=37.5 \mathrm{~mL} \cdot \mathrm{min}^{-1}$ ) and $\mathrm{p}=1$ bar. Finally, The characterization was done by XRD, SEM, BET, and test on the precursor, optimized catalyst, and optimized catalyst after reactor tests, which all were showed the nanosized catalyst particles.
\end{abstract}

Keywords: Fischer-Tropsch synthesis; nanocatalyst; catalyst characterization; wet impregnation method; iron-cobalt-cerium catalyst.

(C) 2020 by the authors. This article is an open-access article distributed under the terms and conditions of the Creative Commons Attribution (CC BY) license (https://creativecommons.org/licenses/by/4.0/).

\section{Introduction}

Fischer-Tropsch Synthesis as a source of good quality liquid fuels, in recent years, it has devoted a large part of the technical, economic, and industrial studies and scientific research to major oil companies [1,2]. At present, fuel and chemical production is based on crude oil. Since methane and coal are much more than crude oil, natural gas and methane can be converted to fuel and chemicals from effective saving, cost, and environmental benefits. To be this process can be very useful in four directions. First, it is one way to convert gas into a liquid that makes transporting easier; secondly, it directly generates portable hydrocarbon-based fuels; the third advantage is that the hydrocarbon fuels they produce are excellent quality. This means that there are very few environmental pollutants and other impurities such as aromatics, sulfur, nitrogen compounds, and heavy metals [3,4]. Therefore the fuels derived from this 
process are referred to as clean fuels. Ultimately the storage of expired resources Oil and its rising cost will make the Fischer Tropsch process more noticeable [3,5,6] and try to improve that day by day. Fischer Tropsch Synthesis is part of the important process of GTL, in which synthesis gas (mainly containing $\mathrm{H}_{2}$ and $\mathrm{CO}$ from coal, natural gas, or natural gas) is converted into a mixture of hydrocarbons. Changes influence this in the catalyst composition, feed $\mathrm{H}_{2} / \mathrm{CO}$ ratio, temperature, pressure, and reactor type. In addition to hydrocarbons, other beneficial chemicals may also be produced, increasing or decreasing the amount of these materials by varying ratios and conditions. Most of the products of the Fischer Trout Process are hydrocarbon fuels (gasoline, diesel fuel, and jet), olefins, waxes, and oxygenates (such as alcohols) [7, 8].

\section{Materials and Methods}

\subsection{Reactions in Fischer-Tropsch synthesis.}

These reactions can be divided into three categories:

- The main reactions are paraffin and olefins $[9,10]$.

$$
\begin{aligned}
& (2 \mathrm{n}+1) \mathrm{H}_{2}+\mathrm{nCO} \rightarrow \mathrm{CnH}_{2 \mathrm{n}}+2+\mathrm{nH}_{2} \mathrm{O} \\
& (\mathrm{n}+1) \mathrm{H}_{2}+2 \mathrm{nCO} \rightarrow \mathrm{CnH}_{2 \mathrm{n}}+2+\mathrm{nCO}_{2} \\
& 2 \mathrm{nH}_{2}+\mathrm{nCO} \rightarrow \mathrm{C}_{\mathrm{n}} \mathrm{H}_{2 \mathrm{n}}+\mathrm{nH}_{2} \mathrm{O} \\
& \mathrm{nH}_{2}+2 \mathrm{nCO} \rightarrow \mathrm{C}_{\mathrm{n}} \mathrm{H}_{2 \mathrm{n}}+\mathrm{nCO}_{2}
\end{aligned}
$$

Reactions (1) and (2) for the production of paraffin and reactions (3) and (4) for the production of olefins. Another reaction, which is a major reaction, is the reaction of gas displacement.

$$
\mathrm{CO}_{2}+\mathrm{H}_{2} \rightarrow \mathrm{CO}+\mathrm{H}_{2} \mathrm{O}
$$

- $\quad$ Side reactions, which are the product of alcohols, are also the reaction of Boudouard (7) in this category. This reaction leads to the formation of coke at the catalyst level and reduces catalytic activity.

$$
\begin{aligned}
& 2 \mathrm{nH}_{2}+\mathrm{nCO} \rightarrow \mathrm{C}_{\mathrm{n}} \mathrm{H}_{2 \mathrm{n}}+2 \mathrm{O}+(\mathrm{n}-1) \mathrm{H}_{2} \mathrm{O} \\
& 2 \mathrm{CO} \rightarrow \mathrm{C}+\mathrm{CO}_{2}
\end{aligned}
$$

- Catalytic changes, which include the reduction of catalyst oxidation, the formation of metal carbide in the production of catalysts, which is well seen in the latter case in the production of iron.

$$
\begin{aligned}
& \mathrm{M}_{\mathrm{x}} \mathrm{O}_{\mathrm{y}}+\mathrm{yH}_{2} \rightarrow \mathrm{yH}_{2} \mathrm{O}+\mathrm{xM} \\
& \mathrm{MxOy}+\mathrm{yCO} \rightarrow \mathrm{yCO}_{2}+\mathrm{xM} \\
& \mathrm{yC}+\mathrm{xM} \rightarrow \mathrm{M}_{\mathrm{x}} \mathrm{C}_{\mathrm{y}}
\end{aligned}
$$

\subsection{Catalytic preparation steps.}

This section will discuss the operations that should be done on the primary catalyst, including [2, 11]: Rinsing; Filtering; Drying; Forming; Calcinations.

\subsection{Rinsing.}

The impurities can be removed with the help of a rinse operation. This will continue to continue until the concentration of undesirable species is reduced to a minimum. Washing is not necessary for catalysts produced by inoculation, and catalysts produced in a coordinating 
manner sometimes have a $\mathrm{pH}$ stabilizing factor with undesirable species that need to be removed. For example, sodium ions in the catalyst can be caused by sodium hydrogen carbonate, sodium carbonate can be title acts as an intrinsic poisoning agent, and even other species that sometimes play the promoter's role must be optimally optimized, so most materials require this action for catalyst precursors. The washing operation has the following goals: Harmful substances are removed from the inside of the catalyst. The water is in the space between the particles instead of the mother solution and the inert molecules; In the washing operation, the water dissolves ions that remain at the solid surface in sedimentation; Exchange some unwanted or unwanted ions by other ions that can easily be decanted by calcination.

\subsection{Filtering.}

Catalysts for filtering in the laboratory can be used Buchner funnel and paper strainers, but commercially available using industrial filter filters.

\subsection{Drying.}

There are various drying methods, including drying in the oven at atmospheric pressure and drying fine droplets of vacuum solvent pre-vacuum solvent, including these methods. Drying can be carried out at a temperature between 100 and $600{ }^{\circ} \mathrm{C}$ [12-14]. Depending on the catalyst's structure and characteristics, the variable's temperature is usually between 100 and $150^{\circ} \mathrm{C}$. The drying time can also be an effective factor in how the catalyst works, depending on the type of structure and the catalyst characteristics. The drying temperature can be in different ranges, which can usually range from $4 \mathrm{~h}$. If the drying rate is high, the high velocity of evaporation in the pores will disrupt the catalyst. However, using the test method and the error at different velocities and temperatures and checking the final catalyst's quality, it is possible to dry using the mathematical model optimally.

\subsection{Forming.}

After drying, depending on the test conditions, the particles' size can be determined by sieving the meshes in one of these ways. It can also occasionally be obtained by peeling or extruding, which usually comes with the receptor (for binding) and softening agents (for ease of forming into powder).

\subsection{Calcinations.}

Technically, the calcining and drying processes are similar. The difference is that drying is carried out at temperatures in the range of $150-1050{ }^{\circ} \mathrm{C}$. However, calcinations sometimes occur at temperatures above $1000{ }^{\circ} \mathrm{C}$. In the process of calcining, the chemical and physical properties of the material change, by doing so, not only the size of the pores but also their distribution. By increasing the calcinations temperature, a clear difference in the pore diameter is created. As a result, the total volume of the pores and their area significantly decreases, one of which is the growth of the growth of the crystals forming the catalyst. In practice, the airflow's calcinations from the catalyst with the gradual increase of temperature pass through until the temperature reaches its maximum. Calcining is very important for the following reasons: Loss of crystalline water molecules, i.e., water molecules that have been bonded with metal atoms, do not get out of the catalyst structure during the drying process due 
to the bond's strength; Exit of unnecessary materials such as binders, lubricants, esophagus, and unstable anions and cations such as chlorine, $\mathrm{NO}_{3}, \mathrm{NH}_{3}$, and $\mathrm{CO}_{2}$; Changes in the distribution of pore size in the catalyst structure; Catalyst reaches the best form in terms of stability, structure, and active phase formation; Achieving mechanical stability; Scattering of metal action and forming it in proper design and structure Sample resuscitation [15].

In the recovery phase, the resulting oxides are streams of hydrogen or a mixture of hydrogen with another gas. The temperature and purity of the reducing agent are important factors in the process of reducing metal oxides. By changing the percentage of the metal present in the catalyst structure or changing the process temperature, it is possible to control their distribution, for example, in iron-based catalysts, with the increase in the temperature of resuscitation of the surface, the surface, the volume of catalyst cavities is reduced and its activity decreases. Cobalt, nickel, and ruthenium are almost always reduced to $\mathrm{H} 2$ at temperatures between $473-723 \mathrm{~K}$ and remain under metallic conditions under reaction conditions.

Fischer-Tropsch Synthesis activity and selectivity on $\mathrm{Co} / \mathrm{C}$ catalysts and its reaction condition has been studied in Table 1 .

Table 1. Reaction Condition on Fischer-Tropsch Synthesis.

\begin{tabular}{l|l|l|l|l} 
Ref. & Catalyst & $\mathbf{T}\left({ }^{\circ} \mathbf{C}\right)$ & GHSV & CO\% \\
\hline$[16]$ & Co/C & 220 & 3600 & $9,22,38$ \\
\hline$[17]$ & ZIF-67 & 500 & 5550 & 60 \\
\hline$[18]$ & Co-BDC & 550 & 3000 & 10.5 \\
\hline$[19]$ & CPO-27(Co) & 500 & 2800 & 1.1 \\
\hline$[20]$ & ZIF-67 & 600 & 6.75 & 34.2 \\
\hline$[21]$ & MOF-1 & 500 & 3600 & 65.1 \\
\hline$[22]$ & $25 \%$ Co/N-NGC & 220 & - & 86.9 \\
\hline$[23]$ & $6.1 \%$ Co/carbon spheres & 232 & - & 21 \\
\hline$[24]$ & $15 \%$ Co-3wt.\%Cr/AC & 220 & - & 45.6 \\
\hline$[25]$ & $10 \%$ Co/N-HCS & 220 & - & 34 \\
\hline$[26]$ & $20 \%$ Co-0.1\%Pt/NaBEA & 250 & 63 \\
Many other researchers are also have done in the field of Fischer -Tropsch $[27-31]$.
\end{tabular}

\subsection{Optimal catalyst preparation method.}

The nanocatalyst in this study was made of three metals, iron (Fe), cobalt $(\mathrm{CO})$, cerium (Ce), by inoculation method. In this method, three half-molar solutions of the metal nitrates $\mathrm{CO}\left(\mathrm{NO}_{3}\right)_{2} .6 \mathrm{H}_{2} \mathrm{O}, \mathrm{Fe}\left(\mathrm{NO}_{3}\right)_{3} .9 \mathrm{H}_{2} \mathrm{O}, \mathrm{Ce}\left(\mathrm{NO}_{3}\right)_{2} .6 \mathrm{H}_{2} \mathrm{O}$ and then another solution containing an equal ratio of metals. The materials were purchased from Merck factory with purity above $97 \%$ that is summarized in Table 2.

Table 2. Material used in the synthesis of catalysts.

\begin{tabular}{c|c|c|c} 
Molecular weight & Purity (\%) & manufacturing factory & Chemical substance \\
\hline 404 & 98 & MERCK & $\mathrm{Fe}\left(\mathrm{NO}_{3}\right)_{1} .9 \mathrm{H}_{2} \mathrm{O}$ \\
\hline 291.04 & 97 & MERCK & $\mathrm{Co}\left(\mathrm{NO}_{3}\right)_{2} .6 \mathrm{H}_{2} \mathrm{O}$ \\
\hline 434 & 98.5 & MERCK & $\mathrm{Ce}\left(\mathrm{NO}_{3}\right)_{2} .6 \mathrm{H}_{2} \mathrm{O}$ \\
\hline 191 & 99 & MERCK & $\mathrm{Al}_{2} \mathrm{O}_{3}$
\end{tabular}

We add a certain amount of solution to $5 \%$ by weight (based on the weight of metals), powdered alumina (calcined at $600{ }^{\circ} \mathrm{C}$ for $6 \mathrm{~h}$ ), and the resulting mixture at different temperatures from 30 to $90{ }^{\circ} \mathrm{C}$ over time $4-8 \mathrm{hr}$ is inoculated in Rotary. Then we straighten it with a Buchner funnel. The precipitate is dried at various temperatures of $90{ }^{\circ} \mathrm{C}$ for a period 6$24 \mathrm{~h}$, called a precursor. 9 precursors are made, as shown in Table 3. 
The resulting precursors were calcined for $6 \mathrm{~h}$ at $600{ }^{\circ} \mathrm{C}$, and final catalysts were obtained. The optimum catalytic catalyst was dried at $90{ }^{\circ} \mathrm{C}$ for 4 hours for 24 hours in an autoclave with a temperature of $120^{\circ} \mathrm{C}$.

Table 3. Synthesized catalysts.

\begin{tabular}{c|c|c|c|c}
$\begin{array}{c}\text { Drying temperature } \\
\left({ }^{\circ} \mathbf{C}\right)\end{array}$ & $\begin{array}{c}\text { Drying time } \\
(\mathbf{h})\end{array}$ & $\begin{array}{c}\text { Inoculation temperature } \\
\left({ }^{\circ} \mathbf{C}\right)\end{array}$ & $\begin{array}{c}\text { Inoculation } \\
\text { time(h) }\end{array}$ & Catalyst \\
\hline 90 & 6 & 60 & 4 & 1 \\
\hline 90 & 24 & 30 & 6 & 2 \\
\hline 150 & 6 & 90 & 6 & 3 \\
\hline 150 & 15 & 30 & 4 & 4 \\
\hline 120 & 15 & 60 & 6 & 5 \\
\hline 120 & 24 & 90 & 4 & 6 \\
\hline 120 & 6 & 30 & 8 & 7 \\
\hline 150 & 24 & 60 & 8 & 8 \\
\hline 90 & 15 & 90 & 8 & 9
\end{tabular}

Table 4. Analysis of the XRD precursor spectrum, optimal catalyst, and catalyst after testing

\begin{tabular}{c|c|c|c|c|c|c|c|c} 
h.K.I & $\begin{array}{c}\text { Nano } \\
\text { Size }\end{array}$ & Number & $\begin{array}{c}\text { Space } \\
\text { group }\end{array}$ & Constant network & $\begin{array}{c}\text { Crystalline } \\
\text { species }\end{array}$ & $\begin{array}{c}\text { Compound } \\
\text { name }\end{array}$ & $\begin{array}{c}\text { Reference } \\
\text { code }\end{array}$ & Type \\
\hline & & & & $\begin{array}{c}\mathrm{a}=5.036 \mathrm{~A}^{\circ} \\
\mathrm{b}=5 / 0360 \mathrm{~A}^{\circ} \\
\mathrm{c}=13 / 7720 \mathrm{~A}^{\circ} \\
\alpha=90^{\circ} \beta=90^{\circ} \\
\delta=90^{\circ}\end{array}$ & Orthorhombic & $\mathrm{FeHO}_{2}$ & 010770247 & Precursor \\
012 & 25.5575 & 13 & $\mathrm{P}-3 \mathrm{M} 1$ & & & \\
\hline
\end{tabular}
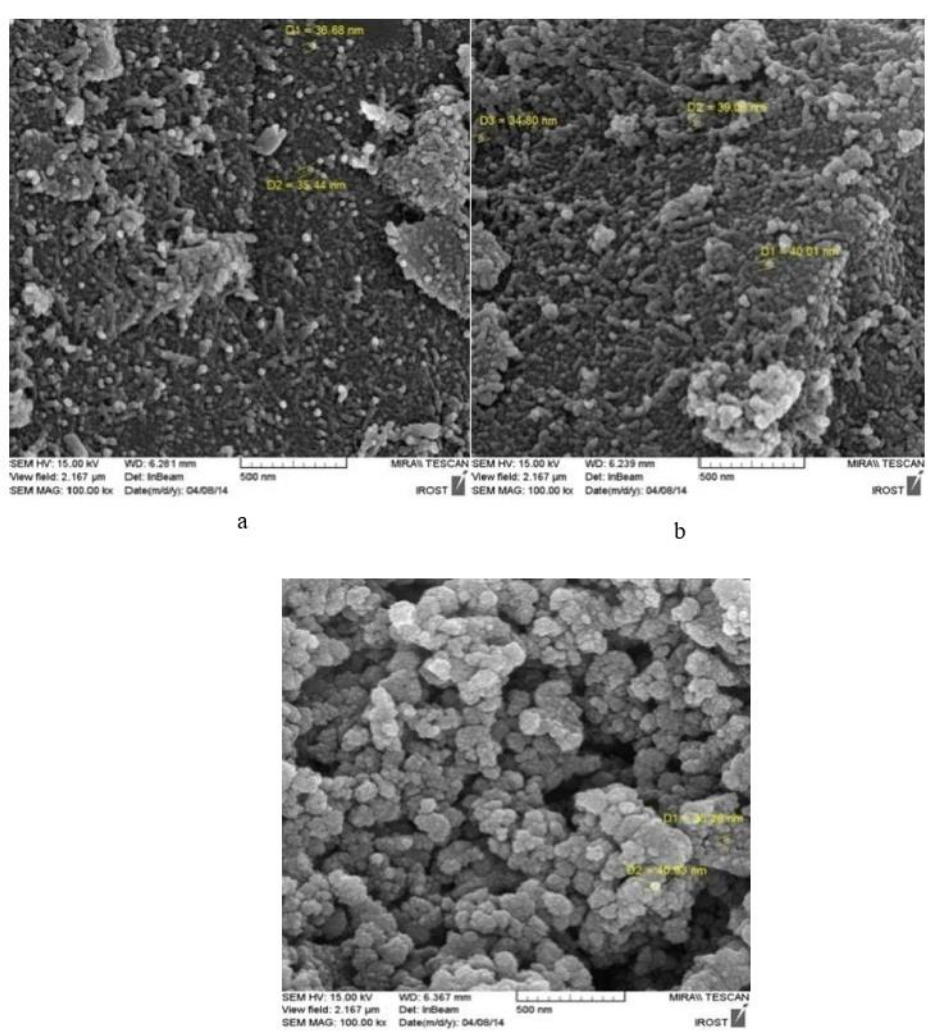

Figure 1. a) the precursor, (b) an optimal catalyst, and (c) a catalyst after SEM test. 
The shape, size, and distribution of crystals are important structural features. This method is an appropriate tool for morphology. The separation problems limit this technique to investigate crystals larger than $5 \mathrm{~nm}$. SEM investigations on many systems have been carried out to identify crystals and studies on the structure of cavities. The SEM machine sample with VEGA/TASCAN model, which is available at Tehran Polymer and Petrochemical Institute, is used. Table 4 presents the XRD results and also gives information about the catalyst.

The comparison of Figures 1.a, 1.b, and 1.c show that the precursor has continuous, dense, and coarse particles. However, during the calcinations process, these particles become smaller and smaller due to the formation of new phases and the release of volatile organic compounds. However, for the catalyst after the test, due to the formation of carbide phases, the catalytic cracking and resuscitation phenomenon is somewhat larger.

Using the BET method, the optimal catalyst area, precursor, and catalyst after the test was examined. The results are presented in Table 5.

Table 5. BET results $\left(\mathrm{m}^{2} / \mathrm{g}\right)$.

\begin{tabular}{c|c|c} 
Catalyst (after testing) & Optimal catalyst & Precursor \\
\hline 90.1120 & 137.6620 & 97.9299
\end{tabular}

The catalysts produced, the calcite catalysts, have a greater surface area than the precursor due to the outflow of water in the precursor that creates a cavity and increases the surface area. Carefully, in the results, it is noted that the catalysts have a slight decrease in surface area after the test, which is due to the filling of catalyst cavities during catalytic operations. The carbide phases in the catalyst after the test indicate the filling of the cavities by the carbides.

\subsection{Laboratory unit reactor test.}

The device's overall work is to mix synthetic gases removed from the capsules with the desired rate and then react to them and then provide the desired solution. Figure 2 shows the schematic of the apparatus that is used in this research.
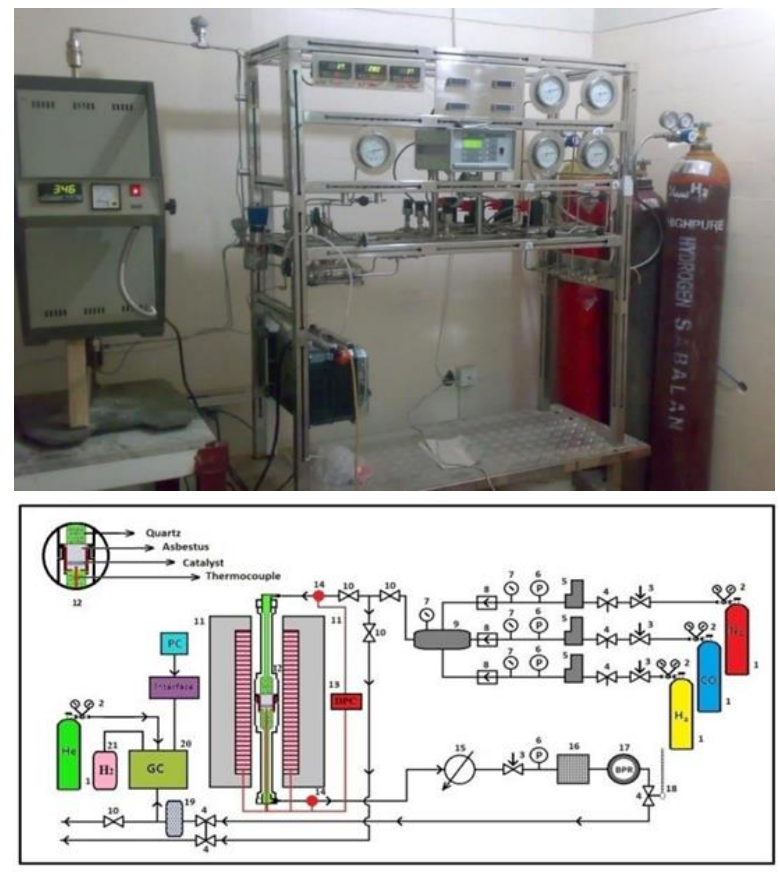

Figure 2. Schematic of the used micro-reactor study of catalytic activity and performance evaluation of catalysts. 
In this section, the conditions for temperature and time of inoculation, temperature and drying time, temperature and recovery time, and calcification and constant spatial velocity were discussed to test the reactor, respectively. As discussed in the previous section (technical notes), the conventional procedure after catalyst construction is to resuscitate the catalyst and test the catalyst in a small reactor and examine its performance on a small scale. Creating a catalyst and changing the inoculation temperature and inoculation time, as well as temperature and drying time, are effective factors; therefore, different conditions were made in nine modes, not the catalyst and the pivotal difference. The catalyst was prepared by inoculation at different inoculation temperature $\left(30,60,90{ }^{\circ} \mathrm{C}\right)$ and different inoculation periods $(4,6$ and $8 \mathrm{hr}$ ) and different drying temperatures $\left(90,120,150^{\circ} \mathrm{C}\right)$ in the duration of time $(6,15,24 \mathrm{hr})$ was developed by Taguchi experimental design method and showed in Table 6.

Table 6. Factors and test levels determined by the Taguchi experimental design.

\begin{tabular}{c|c|c|c} 
Third level & Second level & First level & Parameters \\
\hline 90 & 60 & 30 & Inoculation temperature $\left({ }^{\circ} \mathrm{C}\right)$ \\
\hline 8 & 6 & 4 & Inoculation time $(\mathrm{hr})$ \\
\hline 150 & 120 & 90 & Drying temperature $\left({ }^{\circ} \mathrm{C}\right)$ \\
\hline 24 & 15 & 6 & Drying time $(\mathrm{hr})$
\end{tabular}

The reaction conditions including the resuscitation temperature of $400{ }^{\circ} \mathrm{C}$ by hydrogen for $3 \mathrm{hr}$ and $30 \mathrm{ml} / \mathrm{min}$, and the reaction temperature of $350{ }^{\circ} \mathrm{C}$ with flux $37.5 \mathrm{ml} / \mathrm{min}$ hydrogen and $\mathrm{CO}$ at $\mathrm{H}_{2} / \mathrm{CO}=1$, and the calcinations temperature of $600^{\circ} \mathrm{C}$ for $6 \mathrm{hr}$ and $\mathrm{GHSV}=4500 \mathrm{hr}^{-}$ ${ }^{1}$ were considered the same for all types of catalysts. The results for each catalyst are listed in the optimal catalyst table. The catalyst is chosen as the best catalyst, with the highest $\mathrm{CO}$ conversion rate and selectivity for the desired products, while also having the least selectivity for the methane product. Tables 7 and 8, present the catalytic resuscitation conditions and operation conditions, respectively.

Table 7. Catalytic resuscitation conditions by $\mathrm{H}_{2}$.

\begin{tabular}{|c|c|c|c|}
\hline Pressure(bar) & Flux (mL.min $\left.{ }^{-1}\right)$ & Temperature $\left({ }^{\circ} \mathrm{C}\right)$ & Time(hr) \\
\hline$\sim 1$ & 30 & 400 & 3 \\
\hline
\end{tabular}

Table 8. Conditions for performing a test of a reactor.

\begin{tabular}{c|c|c|c|c} 
Space velocity $\left(\mathbf{h r}^{-1}\right)$ & Pressure $(\mathbf{b a r})$ & Flux $\left(\mathbf{m L}_{\mathbf{m}} \mathbf{m i n}^{-1}\right)$ & Temperature $\left.^{\circ} \mathbf{C}\right)$ & Time $(\mathbf{h r})$ \\
\hline 4500 & 1 & $\begin{array}{c}\mathrm{H}_{2}=37.5 \\
\mathrm{CO}=37.5\end{array}$ & 350 & 1.5
\end{tabular}

\section{Results and Discussion}

\subsection{Operating conditions of catalysts.}

According to each computational chromatogram, according to the formulas, numbers were obtained for each product's selectivity and yield. Optimal products are ethylene and propylene, so ethylene and propylene are considered a good products, and methane is considered undesirable. Other products are identified as (RT). Another point is that the number (RT) is related to how many gas chromatography outputs are. The absence of ethylene or propylene, or both in the tables, means that they are not produced.

In this section, we performed the test steps to obtain the necessary data to optimize temperature and time of inoculation, temperature and drying time. The final Table 9 was obtained after the calculations on the data obtained from the test of the nine catalysts. There are two common methods, one considering the number of experiments with the highest 
selectivity for desired products such as ethylene and propylene, the activity, and the best catalyst's lowest methane production. The results of the activity of products are presented in Figure 3.

Table 9. Optimize temperature and time of inoculation, temperature and drying time

\begin{tabular}{|c|c|c|c|c|c|c|c|c|c|c|c|c|}
\hline $\begin{array}{l}\text { Cat. } \\
\text { No }\end{array}$ & ठ & $\stackrel{\Xi}{0}$ & 导 & $\sum_{\text {되 }}^{\stackrel{\Xi}{\vec{Z}}}$ & 莞 & 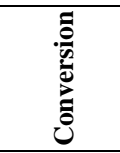 & 迅 & 远 & 远 & $\sum_{\lambda}^{ \pm}$ & $\sum_{\partial}^{\dot{\theta}}$ & $\succ \frac{\dot{\mathrm{C}}}{\mathrm{O}}$ \\
\hline 1 & 5274001 & 506480 & 38231 & - & - & 3.966628 & 0.18274 & - & - & 26.4382 & - & - \\
\hline 2 & 5274001 & 4935496 & 684507 & 9202 & 10014 & 6.418372 & 2.02214 & 0.02718 & 0.02958 & 85.1932 & 1.14527 & 1.24633 \\
\hline 3 & 5274001 & 5005571 & 25519 & 20797 & - & 5.089684 & 0.09506 & 0.07747 & - & 12.9630 & 10.5644 & - \\
\hline 4 & 5274001 & 4803351 & 24866 & 1107 & - & 8.923965 & 0.05283 & 0.00235 & - & 3.05975 & 0.13621 & - \\
\hline 5 & 5274001 & 5025586 & 636360 & 5640 & 29779 & 4.710181 & 2.56168 & 0.02270 & 0.11987 & 11.9521 & 0.10593 & 0.55931 \\
\hline 6 & 5274001 & 5006850 & 113591 & 1780109 & 22329 & 5.065433 & 4.25195 & 66.6330 & 0.08358 & 2.77949 & 43.5579 & 0.05463 \\
\hline 7 & 5274001 & 4951066 & 795087 & 15355 & 24824 & 6.12315 & 2.46206 & 0.04754 & 0.07687 & 44.8121 & 0.86542 & 1.39911 \\
\hline 8 & 5274001 & 4879077 & 684500 & 57897 & 146740 & 7.488129 & 1.73324 & 0.14660 & 0.37156 & 34.8686 & 2.97319 & 7.53557 \\
\hline 9 & 5274001 & 5136379 & 634832 & 8889 & 9236 & 2.609442 & 4.61286 & 0.06459 & 0.06711 & 85.2830 & 1.19414 & 1.24076 \\
\hline
\end{tabular}

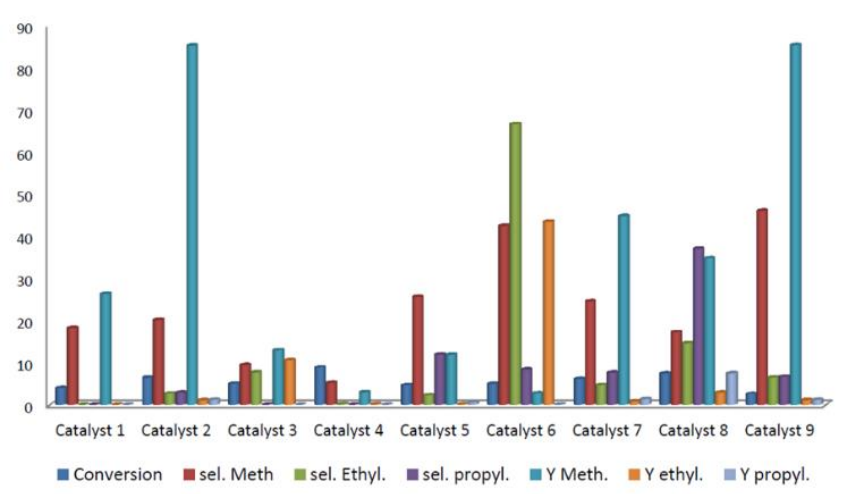

Figure 3. Distribution of selectivity and efficiency (activity) of products from reaction with catalysts.

\subsection{XRD results.}

The precursors of this catalyst are completely amorphous. The identified phases for calcined catalysts are a mixture of iron oxides, cobalt, and cerium before the reactor test. The phases identified for XRD tests after the test are often carbide and metal phases.

\subsection{BET results.}

All of the precursors have a higher surface area than the calcined catalyst before and after the reactor's test due to the outflow of water in the precursor, which in this place is a hole and increases the surface area. After the test, the calcined catalyst shows a slight decrease in surface area than the pre-test specimen due to the mooring.

\subsection{Results from SEM.}

The particle tissue in the precursor and the calcined sample is very different. The particle size in the calcined catalyst is smaller due to the degradation during the calcinations process.

The SEM comparison of the calcined sample before and after the reactor test also shows that the catalyst test has a significant effect on the catalyst's texture and structure, which can be attributed to the formation of metal and carbide phases. 


\section{Conclusions}

The purpose of this research is to obtain an optimal catalyst for inoculums temperatures and inoculums times, as well as the best temperatures and drying times made by wet inoculation. Identification tests included XRD, SEM, BET on the calcined catalyst. The approximate size of the catalyst particle is less than $100 \mathrm{~nm}$ in terms of the XRD spectrum. Two important operations were performed to reduce the mass transfer effects. First, the nanoparticle catalyst reduced the edges and corners. The spatial speed of GHSV $=4500 \mathrm{hr}^{-}$ ${ }^{1}$ was chosen, which could affect the reaction speed and penetration of the hole.

Experiments were carried out at different drying and inoculation temperatures for different periods and to prepare the optimal catalyst for the reactor's test on 9 different catalysts. Finally, the best catalyst obtained was catalyzed at $90{ }^{\circ} \mathrm{C}$ for 4 hours, inoculated at $120{ }^{\circ} \mathrm{C}$ dried for 24 hours, and showed the best performance. It should be noted that all of the catalysts were calcified at $600{ }^{\circ} \mathrm{C}$ for $6 \mathrm{hr}$. The resuscitation temperature was $400{ }^{\circ} \mathrm{C}$ for $3 \mathrm{hr}$, and the hydrogen gas discharge for $30 \mathrm{~mL} / \mathrm{min}$ and $\mathrm{P}=1$ atm were the same for all of them.

\section{Funding}

This research received no external funding.

\section{Acknowledgments}

This research has no acknowledgment.

\section{Conflicts of Interest}

The authors declare no conflict of interest.

\section{References}

1. Aasberg-Petersen, K. Studies in Surface Science and Catalysis. Elsevier Science, 2004; pp. 258-405.

2. Gurbani, A.; Ayastuy, J.L.; González-Marcos, M.P.; Herrero, J.E.; Guil, J.M.; Gutiérrez-Ortiz, M.A. Comparative study of $\mathrm{CuO}-\mathrm{CeO} 2$ catalysts prepared by wet impregnation and deposition-precipitation. International Journal of Hydrogen Energy 2009, 34, 547-553, https://doi.org/10.1016/j.ijhydene.2008.10.047.

3. Schulz, H. Short history and present trends of Fischer-Tropsch synthesis. Applied Catalysis A: General 1999, 186, 3-12, https://doi.org/10.1016/S0926-860X(99)00160-X.

4. Demirbas, A. Combustion Efficiency Impacts of Biofuels. Energy Sources, Part A: Recovery, Utilization, and Environmental Effects 2009, 31, 602-609, https://doi.org/10.1080/15567030701743718.

5. Tavakoli, A.; Sohrabi, M.; Kargari, A. Application of Anderson-Schulz-Flory (ASF) equation in the product distribution of slurry phase FT synthesis with nanosized iron catalysts. Chemical Engineering Journal 2008, 136, 358-363, https://doi.org/10.1016/j.cej.2007.04.017.

6. Takeshita, T.; Yamaji, K. Important roles of Fischer-Tropsch synfuels in the global energy future. Energy Policy 2008, 36, 2773-2784, https://doi.org/10.1016/j.enpol.2008.02.044.

7. Marano, J.J. Options for Upgrading \& Refining Fischer-Tropsch Liquids. 2nd International Freiberg Conference on IGCC \& XtL Technologies: Freiberg,Germany. 2007.

8. Raje, A.; Inga, J.R.; Davis, B.H. Fischer-Tropsch synthesis: Process considerations based on performance of iron-based catalysts. Fuel 1997, 76, 273-280, https://doi.org/10.1016/S0016-2361(96)00185-8.

9. Dry, M.E. Fischer-Tropsch reactions and the environment. Applied Catalysis A: General 1999, 189, 185190, https://doi.org/10.1016/S0926-860X(99)00275-6.

10. Dalmon, J.A.; Martin, G.A. The kinetics and mechanism of carbon monoxide methanation over silicasupported nickel catalysts. Journal of Catalysis 1983, 84, 45-54, https://doi.org/10.1016/00219517(83)90084-2.

11. Vásquez, P.G.; Cáceres, C.V.; Blanco, M.N.; Thomas, H.J. Prediction of concentration profiles in alumina spheres impregnated with molybdenum solutions. International Communications in Heat and Mass Transfer 1989, 16, 581-591, https://doi.org/10.1016/0735-1933(89)90061-4. 
12. Bilbao-Sáinz, C.; Andrés, A.; Fito, P. Hydration kinetics of dried apple as affected by drying conditions. Journal of Food Engineering 2005, 68, 369-376, https://doi.org/10.1016/j.jfoodeng.2004.06.012.

13. Arsalanfar, M.; Mirzaei, A.A.; Bozorgzadeh, H.R.; Atashi, H.; Shahriari, S.; Pourdolat, A. Structural characteristics of supported cobalt-cerium oxide catalysts used in Fischer-Tropsch synthesis. Journal of Natural Gas Science and Engineering 2012, 9, 119-129, https://doi.org/10.1016/j.jngse.2012.05.015.

14. Mirzaei, A.A.; Arsalanfar, M.; Bozorgzadeh, H.R.; Samimi, A.J.P.C.R. A review of Fischer-Tropsch synthesis on the cobalt based catalysts. Physical Chemistry Research 2014, 2, 179-201, https://dx.doi.org/10.22036/pcr.2014.5786.

15. Aluha, J; Yongfeng, H.N.A. Catalysts 2017, 1-19.

16. Luo, Q.-X.; Guo, L.-P.; Yao, S.-Y.; Bao, J.; Liu, Z.-T.; Liu, Z.-W. Cobalt nanoparticles confined in carbon matrix for probing the size dependence in Fischer-Tropsch synthesis. Journal of Catalysis 2019, 369, 143156, https://doi.org/10.1016/j.jcat.2018.11.002.

17. Li, N.; Ma, C.-P.; Zhang, C.-H.; Yang, Y.; Li, Y.-W. Low-cost preparation of carbon-supported cobalt catalysts from MOFs and their performance in $\mathrm{CO}$ hydrogenation. Journal of Fuel Chemistry and Technology 2019, 47, 428-437, https://doi.org/10.1016/S1872-5813(19)30020-9.

18. Rivera-Torrente, M.; Hernández Mejía, C.; Hartman, T.; de Jong, K.P.; Weckhuysen, B.M. Impact of Niobium in the Metal-Organic Framework-Mediated Synthesis of Co-Based Catalysts for Synthesis Gas Conversion. Catalysis Letters 2019, 149, 3279-3286, https://doi.org/10.1007/s10562-019-02899-0.

19. Chen, Y.; Li, X.; Nisa, M.U.; Lv, J.; Li, Z. ZIF-67 as precursor to prepare high loading and dispersion catalysts for Fischer-Tropsch synthesis: Particle size effect. Fuel 2019, 241, 802-812, https://doi.org/10.1016/j.fuel.2018.12.085.

20. Janani, H.; Mirzaei, A.A.; Rezvani, A. Correlation of metal-organic framework structures and catalytic performance in Fischer-Tropsch synthesis process. Reaction Kinetics, Mechanisms and Catalysis 2019, 128, 205-215, https://doi.org/10.1007/s11144-019-01626-5.

21. Taghavi, S.; Tavasoli, A.; Asghari, A.; Signoretto, M. Loading and promoter effects on the performance of nitrogen functionalized graphene nanosheets supported cobalt Fischer-Tropsch synthesis catalysts. International Journal of Hydrogen Energy 2019, 44, 10604-10615, https://doi.org/10.1016/j.ijhydene.2019.03.015.

22. Kuang, T.; Lyu, S.; Liu, S.; Zhang, Y.; Li, J.; Wang, G.; Wang, L. Controlled synthesis of cobalt nanocrystals on the carbon spheres for enhancing Fischer-Tropsch synthesis performance. Journal of Energy Chemistry 2019, 33, 67-73, https://doi.org/10.1016/j.jechem.2018.08.012.

23. Zhao, Z.; Lu, W.; Feng, C.; Chen, X.; Zhu, H.; Yang, R.; Dong, W.; Zhao, M.; Lyu, Y.; Liu, T.; Jiang, Z.; Ding, Y. Increasing the activity and selectivity of Co-based FTS catalysts supported by carbon materials for direct synthesis of clean fuels by the addition of chromium. Journal of Catalysis 2019, 370, 251-264, https://doi.org/10.1016/j.jcat.2018.12.022.

24. Dlamini, M.W.; Phaahlamohlaka, T.N.; Kumi, D.O.; Forbes, R.; Jewell, L.L.; Coville, N.J. Post doped nitrogen-decorated hollow carbon spheres as a support for Co Fischer-Tropsch catalysts. Catalysis Today 2020, 342, 99-110, https://doi.org/10.1016/j.cattod.2019.01.070.

25. Flores, C.; Batalha, N.; Marcilio, N.R.; Ordomsky, V.V.; Khodakov, A.Y. Influence of Impregnation and Ion Exchange Sequence on Metal Localization, Acidity and Catalytic Performance of Cobalt BEA Zeolite Catalysts in Fischer-Tropsch Synthesis. ChemCatChem 2019, 11, 568-574, https://doi.org/10.1002/cctc.201800728.

26. Gavrilović, L.; Save, J.; Blekkan, E.A. The Effect of Potassium on Cobalt-Based Fischer-Tropsch Catalysts with Different Cobalt Particle Sizes. Catalysts 2019, 9, https://doi.org/10.3390/catal9040351.

27. [Dai, Y.; Zhao, Y.; Lin, T.; Li, S.; Yu, F.; An, Y.; Wang, X.; Xiao, K.; Sun, F.; Jiang, Z.; Lu, Y.; Wang, H.; Zhong, L.; Sun, Y. Particle Size Effects of Cobalt Carbide for Fischer-Tropsch to Olefins. ACS Catalysis 2019, 9, 798-809, https://doi.org/10.1021/acscatal.8b03631.

28. Guo, S.; Wang, Q.; Wang, M.; Ma, Z.; Wang, J.; Hou, B.; Chen, C.; Xia, M.; Jia, L.; Li, D. A comprehensive insight into the role of barium in catalytic performance of $\mathrm{Co} / \mathrm{Al} 2 \mathrm{O} 3$ catalyst for Fischer-Tropsch synthesis. Fuel 2019, 256, https://doi.org/10.1016/j.fuel.2019.115911.

29. Tian, Z.; Wang, C.; Yue, J.; Zhang, X.; Ma, L. Effect of a potassium promoter on the Fischer-Tropsch synthesis of light olefins over iron carbide catalysts encapsulated in graphene-like carbon. Catalysis Science \& Technology 2019, 9, 2728-2741, https://doi.org/10.1039/c9cy00403c.

30. Becker, H.; Güttel, R.; Turek, T. Performance of diffusion-optimised Fischer-Tropsch catalyst layers in microchannel reactors at integral operation. Catalysis Science \& Technology 2019, 9, 2180-2195, https://doi.org/10.1039/c9cy00457b. 